\title{
KEBIJAKAN PENDIDIKAN ISLAM MASA PENJAJAHAN JEPANG
}

\author{
Miftahur Rohman \\ STIT Bustanul ‘Ulum Lampung Tengah \\ miftah@stitbustanululum.ac.id
}

\begin{abstract}
ABSTRAK
Pendidikan Islam di masa penjajahan Jepang dijadikan sebagai alat untuk menguatkan kedudukan Pemerintah Jepang di Nusantara guna menghadapi ancaman Sekutu. Kenyataan yang diperoleh dari sumbersumber-sumber sejarah. Awalnya, kedatangan Jepang ke Nusantara disambut dengan terbuka oleh rakyat Indonesia. Jepang datang ke Indonesia dengan membawa semangat kemerdekaan dan pembebasan dari pemerintahan kolonial Belanda. Kedatangan Jepang dipermudah oleh kelompok-kelompok Islam penentang anti-Belanda. Namun belakangan hal tersebut hanya sebagai semboyan Jepang guna memperoleh simpatik masyarakat Indonesia, khususnya golongan Islam. Bila kebijakan pendidikan pemerintah kolonial Belanda adalah misi Kristenisasi, maka pada pendudukan Jepang terjadi peralihan drastis karena titik tumpu Jepang bukan pada agama Kristen. Misi khas dari kebijakan pendidikannya tidak lain adalah menipponkan bangsa dan umat Islam di Indonesia.
\end{abstract}

\section{Kata Kunci}

Kebijakan pendidikan, penjajahan Jepang, Nipponisasi 


\section{PENDAHULUAN}

Pergantian kekuasaan dari pemerintahan kolonial Belanda kepada pemerintahan pendudukan Jepang turut mempengaruhi wajah pendidikan nusantara. Pemerintahan Jepang yang menjajah lebih pendek, sekitar 3.5 tahun, meninggalkan jejak pendidikan yang berbeda dengan pemerintahan kolonial Belanda yang berkuasa di Nusantara sekitar 350 tahun. Jepang yang menduduki Indonesia sejak 8 Maret 1942 hingga Agustus 1945, banyak menimbulkan reaksi yang bersifat konflik fisik, ekonomi, politik maupun dalam bidang pendidikan.

Sejak datang pertama kali ke Nusantara, Jepang mendapatkan penyambutan yang positif dari rakyat Indonesia yang sudah ratusan tahun terkungkung oleh penjajahan colonial Belanda. Kedatangan Jepang membawa secercah harapan baru bagi bangsa Indonesia yang ingin lepas dari penjajahan dan menjadi negara yang merdeka dan berdaulat. Namun, bagaikan pinang dibelah dua ternyata kebijakan politik pemerintahan jepang tidak jauh berbeda dengan Belanda. Ekspetasi yang besar rakyat Indonesia untuk memperoleh kemakmuran hanyalah angan-angan kosong yang tak dipenuhi oleh Jepang dikemudian hari. Pendudukan Jepang justru menambah kesengsaraan rakyat yang telah ratusan menderita. Jepang hanya mengeksploitasi kekayaan dan sumber daya rakyat Indonesia.

Kebijakan politik dan pendidikan Jepang jauh dari tujuan untuk mensejahterakan rakyat. Dalam makalah ini, penulis hanya membatasi pembahasan kebijakan Jepang dalam bidang politik-pendidikan. Kebijakan-kebijakan dalam bidang pendidikan, akan dikaji lebih mendalam dalam makalah ini. Kebijakan politik, sosial dan yang lainnya juag dikupas sedikit. Untuk mendapatkan pengetahuan yang lebih komprehensif, kita dapat cari dan baca dalam literatur yang ada untuk memperkaya pengetahuan kita. Setelah mengkaji pembahasan ini, 
diharapkan pemikiran analitis dan kritis dapat kita kembangkan untuk masa depan bangsa yang lebih baik.

\section{KEBIJAKAN POLITIK JEPANG}

Bangsa Jepang muncul sebagai negara kuat di Asia. Ketika dunia dilanda perang dunia II, jepang tidak tinggal diam dan ikut andil dalam perang tersebut. Jepang mendapatkan prestasinya ketika menghadapi Rusia. Jepang bercita-cita menjadi pemimpin Asia Timur Raya. Belanda yang sekian lama menjajah Indonesia dapat dikalahkan oleh Jepang. Sehingga akhirnya kekuasaan pemerintahan Nusantara beralih dari pemerintah Kolonial Belanda kepada Jepang. ${ }^{1}$

Kedatangan Jepang ke Nusantara disambut dengan terbuka oleh rakyat Indonesia. Jepang datang ke Indonesia dengan membawa semangat kemerdekaan dan pembebasan dari pemerintahan kolonial Belanda. Kedatangan Jepang dipermudah oleh kelompok-kelompok Islam penentang anti-Belanda. Rakyat dikebanyakan daerah di Jawa menyambut pasukan-pasukan Jepang dengan suka cita dengan mengibarkan bendera Jepang dan Indonesia. ${ }^{2}$ Nampaknya inilah strategi Jepang untuk mendapatkan simpati dari rakyat Indonesia.

Kedatangan Jepang ke Indonesia dengan melucuti tentara sekutu dibarengi dengan semangat gerakan “Tiga $A^{\prime}$ yaitu Nippon pemimpin Asia, Nippon pelindung Asia dan Nippon cahaya Asia. Kampanye slogan yang dimulai sejak Mei sampai Desember 1942, pelaksanaannya diserahkan kepada bangsa Indonesia sendiri, yakni Mr. Syamsudin yang dibalik itu dibarengi dengan dilarangnya semua organisasi rakyat, kamudian diganti dengan mendirikan gerakan-gerakan semisal Djawa

\footnotetext{
${ }^{1}$ Muhammad Rifa'I, Sejarah Pendidikan Nasional, (Yogyakarta: Ar-ruzz Media, 2011), hlm. 84

${ }^{2}$ Harry J. Benda, Bulan Sabit dan Matahari Terbit, (Jakarta: Pustaka Jaya, 1980), hlm. $165-167$
} 
Hooko Kai (Kebaktian Rakyat Jawa), Pusat Tenaga Rakyat (Putera) dan lainlain. ${ }^{3}$ Putera dipimpin oleh orang Indonesia yang tergabung dalam empat serangkai yakni Ir. Soekarno, Moh. Hatta, Ki Hajar Dewantara dan Mas Mansyur. Pembentukan organisasai Putera ini bertujuan untuk menggalang massa dan memperoleh dukungan rakyat Indonesia. ${ }^{4}$

Majelis Islam A'la Indonesia (MIAI) terus beroperasi, sekalipun kemudian dibubarkan dan diganti dengan Majelis Syuro Muslimin Indonesia (Masyumi) yang menyertakan dua ormas besar Islam, Muhammadiyah dan NU. Masyumi dipimpin oleh KH. Hasyim Asyari. Pemerintah Jepang juga mengizinkan ulama dan pemimpin nasionalis membentuk barisan Pembela Tanah Air (PETA) yang belakangan menjadi cikal-bakal TNI di zaman kemerdekaan ${ }^{5}$

Kebijakan politik Jepang tersebut nyatanya tidak mendapat simpatik rakyat Indonesia, yang kemudian hari melakukan pemberontakan. Setelah Jepang datang dengan membawa misi membebaskan rakyat Indonesia dari penjajahan kolonial Belanda dan melucuti tentara sekutu, ternyata tidak lain hanya untuk menduduki dan menjajah Indonesia. Jepang yang terlibat dalam perang dunia II melawan sekutu, melebarkan imperium kekuasaannya dengan mengambil alih sebagian negara jajahan sekutu di penjuru dunia.

Pada tahun 1942 didirikan Bait al-Mal oleh Wiranata Kusuma di Bandung. Organisasi ini bertujuan membantu rakyat dalam mengatasi kesulitan ekonomi akibat dislokasi ekonomi. Bait al-Mal menampung penyaluran zakat dan membagikannya kepada rakyat yang kekuarangan. Keberhasilan organisasi ini di Bandung menarik perhatian pemimpin Islam di Jakarta sehinggal didirikan Bait al-Mal yang lain diberbagai hlm. 112-113

${ }^{3}$ Abdurrahman Assegaf, Pendidikan Islam di Indonesia, (Yogyakarta: Suka Press, 2007),

${ }^{4}$ J. Benda, Bulan Sabit.... hlm. 200-202

${ }^{5}$ Zuhairini,dkk, Sejarah Pendidikan Islam, (Jakarta, PT. Bumi aksara, 2000), hlm.151 
daerah oleh para pemimpin MIAI. Perkembangan yang cepat Bait al-Mal membuat Jepang menghentikan perluasannya. Menurut Harry J. benda hal tersebut menunjukkan keberatan Jepang atas usaha-usaha MIAI yang menyebarluaskan pembentukan Bait al-Mal tanpa melibatkan Shumubu (kantor urusan Agama bentukan Jepang). Kemudian MIAI dibubarkan dan diganti dengan Masyumi. ${ }^{6}$ Masyumi didirikan menggantikan MIAI pada tanggal 22 Nopember 1943 dan diberi status hukum oleh pemerintah Jepang pada 01 Desember 1943. Anggota mayoritasnya ialah NU dan Muhammadiyah namun tidak membatasi, semua organisasi Islam bisa masuk asalkan telah diberi status hokum oleh pemerintah militer Jepang. ${ }^{7}$

Diciptakannya sebuah organisasi yang baru, Majlis Syuro Muslim Indonesia (Masyumi) yang langsung dilegalkan oleh pemerintah militer Jepang merupakan kemenangan politik Jepang terhadap Islam. Setiap kiyai dan ulama secara pribadi dapat menjadi anggota Masyumi dengan persetujuan Syumubu. ${ }^{8}$ Terlihat jelas kebijakan politik Jepang jika dilihat dari luar menunjukkan kepedulian atau sikap pro Jepang terhadap umat Islam, namun tujuan sebenarnya Jepang ialah untuk kepentingannya dalam memperoleh dukungan penduduk Indonesia melawan sekutu. Rakyat Indonesia tentu tidak segampang itu untuk dibodohi, mereka memanfaatkan organisasi-organisasi Islam untuk kepentingan bangsa dan umat Islam yang telah bosan dengan penderitaan penjajahan. Bait al-Mal yang kemudian menjadi sayap cabang MIAI merupakan bukti persatuan dan kebersamaan rakyat untuk melawan penidasan.

\section{KEBIJAKAN PENDIDIKAN ISLAM MASA PENJAJAHAN JEPANG}

\footnotetext{
${ }^{6}$ J. Benda, Bulan Sabit..... hlm. 180-182

${ }^{7}$ Ibid. hlm. 185

${ }^{8}$ Ibid. hlm. 186-187
} 
Bila kebijakan pendidikan pemerintah kolonial Belanda adalah misi Kristenisasi, maka pada pendudukan Jepang terjadi peralihan drastis karena titik tumpu Jepang bukan pada agama Kristen. Misi khas dari kebijakan pendidikannya tidak lain adalah menipponkan bangsa dan umat Islam di Indonesia, dalam arti pengalihan budaya dari akar keIndonesiaan ke urat budaya Nippon, sebagaimana yang pernah dilakukannya pada Manchuria, Korea dan Formosa (Taiwan) sebelum Perang Dunia II. ${ }^{9}$ Upaya Nipponisasi tampak pada beberapa gerakan diantaranya yang telah disebutkan diatas yakni slogan "Tiga A". Slogan tersebut tidak lain hanyalah untuk menarik simpatik bangsa Indonesia, khususnya umat Islam untuk bersama-sama Jepang memenagkan perang Asia dibawah pimpinan Dai Nippon.

Melalui trik Nipponisasi bahasa, bahasa-bahasa yang digunakan seperti bahasa Inggris, Amerika dan Belanda dilarang untuk dijadikan komunikasi baik lisan maupun tulisan. Bahasa Arab yang semula digunakan juga dilarang penggunaannya. Pelarangan tersebut juga dilakukan dalam kegiatan pendidikan di sekolah-sekolah. Pemerintah Nippon hanya mengijinkan penggunaan bahasa Indonesia sebagai bahasa pertama, dan bahasa Jepang sebagai bahasa kedua dalam komunikasi tak terkecuali dalam pendidikan. Pelarangan penggunaan bahasa-bahasa tersebut terutama terhadap bahasa Belanda yang bertujuan untuk menghilangkan pengaruh penjajah Belanda yang telah sekian lama menjajah Indonesia dari berbagai aspek. ${ }^{10}$

Penggunaan bahasa Indonesia dalam segala aspek pendidikan memberikan dampak yang positif bagi perkembangan bahasa Indonesia. Penduduk yang tinggal di daerah pedesaan yang sebelumnya tidak mengenal bahasa Indonesia menjadi lebih mengenal bahasa negerinya

\footnotetext{
${ }^{9}$ Assegaf, Pendidikan.... Hlm.112

${ }^{10}$ Ibid. hlm.113-114
} 
sendiri. Perlu dicatat bahwa pada masa Kolonial Belanda, selain menggunakan bahasa Asing, disekolah-sekolah juga ada yang menggunakan bahasa daerah dalam proses pembelajaran.

Nipponisasi lain yang dilakukan Jepang ialah propaganda. Propaganda bagi rakyat pedesaan yang mayoritas buta huruf dan kurang terdidik dilakukan melalui hiburan, berupa: film layar lebar, drama, wayang kulit, tari, nyanyian dan radio. Sedangkan untuk masyarakat perkotaan yang umumnya sudah terbiasa baca tulis serta terdidik, maka propaganda yang diterapkan lewat media cetak, surat kabar dan sejenisnya disamping masih menggunakan kategori pertama. ${ }^{11}$

Propaganda via radio misalnya bertujuan untuk menyampaikan informasi pidato pemerintah Jepang. Menyampaikan pendidikan politik baik yang langsung disampaikan pemerintah Jepang ataupun yang melalui tokoh nasionalis terkenal seperti Ir. Soekarno dan yang lainnya. Selain itu, radio juga sebagai media belajar rakyat terhadap bahasa Jepang, mendengarkan lagu-lagu dan ceramah berbagai topik termasuk mengenai pendidikan Islam.

Nipponisasi selanjutnya adalah melalui indoktrinisasi. Jepang membentuk wadah pelatihan perjuangan, antara lain: Seindojo (Panti Latihan Militer), Seinekurensho (Pusat Latihan Pemuda), Seindean (Barisan Pemuda), Keibodan (Barisan Pembantu Polisi), Peta (Pembela Tanah Air) dan juga Hizbullah yang banyak diikuti kalangan santri dan kiai. Mereka diasramakan untuk dikader dan diindoktrinisasi. ${ }^{12}$ Bagi Jepang, ulama merupakan alat yang paling efektif untuk menyebarkan pengaruh dimasyarakat pedesaan. Secara cerdik orang-orang Jepang bersikap yang berlawanan dengan kolonial Belanda. Mereka mengakui dan berusaha

\footnotetext{
${ }^{11}$ Ibid. hlm.115-116

${ }^{12}$ Ibid. hlm. 116
} 
untuk memanfaatkan posisi kunci kaum ulama didalam masyarakat Indonesia. Usaha-usaha tersebut banyak dilakukan oleh Shumubu. ${ }^{13}$

Shumubu mengadakan perjalanan keliling jawa dan mengundang konferensi kiai-kiai setempat. Sesudah Gunseikan mengumumkan kebijaksanaan Jepang terhadap rakyat Islam pedesaan yang akan menjadikan kiai-kiai dan guru-guru agama Islam jadi pemimpin front sipil dan bertugas menjamin keamanan dan kesiagaan rakyat. Antara Juli 1943 sampai Mei 1945 diadakannya penataran para kiai selama 30 hari setiap angkatan. Didalam penataran ini para ulama diindoktrinasi dengan ide-ide dan propaganda Jepang. Setiap angkatan diikuti 60 orang ulama dari 20 karisidenan di Jawa. Syarat bagi peserta adalah memiliki pengaruh yang luas, perpengetahuan luas, berposisi sosial baik dan karakter yang tidak tercela. Dalam penataran ini para ulama diasrmakan dan tidak boleh berhubungan dengan public. Mereka harus hidup dalam suasana dan ideologi Jepang. ${ }^{14}$

Indoktrinisasi tersebut dirasa yang paling efektif oleh pemerintah Jepang. Diharapkan setelah dikarantina, diberikan pendidikan selama 30 hari, faham-faham Nippon dapat tertanam dalam pemikiran ulama dan kiai. Karena mereka mempunyai pengaruh besar dikalangan masyarakat. Hemat penulis, anggapan tersebut tampaknya tidak sepenuhnya benar dan terealisasi. Banyak kiai dan ulama yang akhirnya membentuk gerakan pembebasan untuk melakukan pemberontakan pemerintahan penjajahan Jepang.

Sebagai contoh adalah perlawanan di Aceh yang dipimpin oleh ulama muda Tengku Abdul Jalil, guru mengaji di Cot Plieng Lok Seumawe. Usaha Jepang untuk membujuk sang ulama tidak berhasil, sehingga Jepang melakukan serangan mendadak di pagi buta sewaktu

\footnotetext{
${ }^{13}$ J. Benda, Bulan Sabit..... hlm. 166

14 J. Benda, Bulan Sabit.... hlm. 167-170
} 
rakyat sedang melaksanakan shalat Subuh. Dengan persenjataan sederhana/seadanya rakyat berusaha menahan serangan dan berhasil memukul mundur pasukan Jepang untuk kembali ke Lhokseumawe. Begitu juga dengan serangan kedua, berhasil digagalkan oleh rakyat. Baru pada serangan terakhir (ketiga) Jepang berhasil membakar masjid sementara pemimpin pemberontakan (Teuku Abdul Jalil) berhasil meloloskan diri dari kepungan musuh, namun akhirnya tertembak saat sedang shalat. ${ }^{15}$

Selain itu, contoh lain terjadi di pesantren Sukamanah Jawa Barat (Singaparna) di bawah pimpinan KH. Zainal Mustafa, tahun 1943. Beliau menolak dengan tegas ajaran yang berbau Jepang, khususnya kewajiban untuk melakukan Seikerei setiap pagi, yaitu memberi penghormatan kepada Kaisar Jepang dengan cara membungkukkan badan ke arah matahari terbit. Kewajiban Seikerei ini jelas menyinggung perasaan umat Islam Indonesia karena termasuk perbuatan syirik/menyekutukan Tuhan. ${ }^{16}$ Selain itu beliaupun tidak tahan melihat penderitaan rakyat akibat tanam paksa. Kedua contoh diatas membuktikan indoktrinisasi yang dilakukan Jepang tidak berhasil. Bahkan semakin menumbuhkan nasionalisme dan patriotisme rakyat kepada bangsa dan negara.

\section{SISTEM PENDIDIKAN ISLAM ERA PENJAJAHAN JEPANG}

Bangsa Jepang muncul sebagai bangsa kuat di Asia. Ketika kondisi dunia saat itu terjadi perang, Jepang tak tinggal diam dan menampilkan diri ikut dalam peperangan tersebut. Jepang mendapatkan prestasinya ketika menghadapi Rusia. Jepang bercita-cita besar yaitu menjadi pemimpin Asia Timur Raya. Jepang akhirnya menduduki Indonesia dan menaklukan Belanda yang telah lama menjajah. Sekolah-sekolah yang ada

15 Faza Adhima, "Sejarah Indonesia pada Masa Penjajahan Jepang" dalam http://www.slideshare.net, diakses 05 Nopember 2014.

${ }^{16}$ Ibid. 
di zaman Belanda diganti dengan system Jepang. Selama Jepang menjajah Indonesia, hampir setiap hari hanya diisi dengan latihan perang atau bekerja. Jika ada kegiatan-kegiatan sekolah, hal tersebut tidak jauh dari konteks peperangan. Kegiatan yang dikatakan berhubungan dengan sekolah tersebut, antara lain:

1. Mengumpulkan batu dan pasir untuk kepentingan perang.

2. Membersihkan bengkel-bengkel dan asrama militer.

3. Menanam ubi-ubian dan sayur-sayuran di pekarangan sekolah untuk persediaan bahan makanan.

4. Setiap pagi wajib mengucapkan sumpah setia kepada kaisar Jepang, lalu dilatih kemiliteran.

5. Menanam pohon jarak untuk bahan pelumas. ${ }^{17}$

Memang kehadiran Jepang di Indonesia dapat menanamkan jiwa "berani" pada bangsa Indonesia. Akan tetapi semua itu dilakukan hanya untuk kepentingan Jepang. Dalam bidang sosial-politik telah disebutkan diatas, kedatangan Jepang hanya untuk menguras kekayaan Indonesia. Menindas penduduk pribumi dengan sistem kerja paksa (romusa). Pendidikan pada zaman penjajahan jepang ialah untuk memenuhi tanaga cuma-cuma (romusha) dan prajurit-prajurit untuk membantu peperangan bagi kepentingan Jepang. Oleh karena itu pelajar-pelajar diharuskan mengikuti latihan fisik, latihan kemilitiran dan indoktrinasi. ${ }^{18}$ Namun bangsa kita dapat menyadari hal itu. Dengan demikian, perjuangan kemerdekaan bangsa Indonesia semakin gigih dan termotifasi untuk mewujudkan bangsa yang berdaulat, bebas dari penindasan. ${ }^{19}$

\footnotetext{
${ }^{17}$ Rifa'i, Sejarah Pendidikan... hlm. 84

18 Setiyadi, Pendidikan di Indonesia dari Zaman ke Zaman, (Jakarta: Departemen Pendidikan dan Kebudayaan, 1979), hlm. 138

${ }^{19}$ Rifa'i, Sejarah Pendidikan.... Hlm. 85
} 
Tujuan pendidikan di zaman penjajahan Jepang tidaklah banyak yang dapat diuraikan, sebab murid hanya disibukkan dengan peperangan sehingga perhatian dalam pendidikan sangat sedikit. Rayuan Jepang terhadap bangsa Indonesia yang mengatakan bahwa Jepang adalah "saudara tua" yang datang ke Indonesia untuk mencapai kemakmuran bersama di Asia Timur Raya atau yang terkenal dengan hakko ichiu sebagai landasan utama pendidikan pada zaman pendudukan Jepang. ${ }^{20}$

Penjajah Jepang mengambil kebijakan bahwa bahasa bahasa Belanda dilarang digunakan sama sekali baik di kantor-kantor maupun di sekolahsekolah. Sedangkan bahasa Jepang menjadi bahasa kedua. Selama masa pendudukan Jepang inilah bahasa Indonesia berkembang dan dimodernkan sehingga menjadi bahasa pergaulan dan bahasa ilmiah. ${ }^{21}$ Pada masaa ini nasionalisme tumbuh dengan sempurna, masyarakat pedesaan dan dan masyarakat kecil yang sejak awal tidak mendapatkan pendidikan barat Belanda, memiliki peluang untuk meningkatkan diri dalam kemampuan penggunaan bahasa Indonesia. Mereka bersemangat mempelajari bahasa Indonesia, yang harus mereka pahami sejak dari sekolah rendah sampai sekolah menengah. ${ }^{22}$ Disudut lain dapat kita lihat secara konkret tujuan pendidikan zaman penjajahan Jepang adalah menyediakan tenaga kerja cuma-cuma (romusha) dan prajurit-prajurit untuk membantu Jepang dalam perang.

Berbeda dengan Jepang, pemerintah kolonial Belanda yang menjajah Indonesia sebelum Jepang menerapkan politik devide et empera. Yang menciptakan situasi konflik antar golongan dan memusuhi ulama. Kebijakan tersebut berimbas pada sistem pendidikan. Terjadi diskriminasi antara golongan. Golongan Eropa atau yang dipersamakan dengannya

\footnotetext{
${ }^{20}$ Ibid. hlm. 85

${ }^{21}$ Ibid. hlm. 85

22 Agus Salim, Indonesia Belajarlah! Membangun Pendidikan Indonesia, (Yogyakarta:
} Tiara Wacana, 2007), hlm. 213 
mengikuti pendidikan di ELS (Europese Lagere School) yakni sekolah dasar selama 7 tahun. Kemudianj HBS (Hogere Burger School) yang sederajat SMU selama 5 tahun. Lalu sekolah tinggi yang lamanya disesuaikan dengan jurusannya, untuk jurusan hukum melanjutkan ke RHS selama 6 tahun, jurusan kedokteran ke GHS selama 5 tahun. Jadi rata-rata interval waktu yang dibutuhkan untuk menempuh pendidikan dasar sampai pendidikan tinggi golongan ini dibutuhkan waktu 17 sampai 18 tahun. ${ }^{23}$

Sedangkan untuk golongan bumiputera atau yang dipersamakan dengannya yakni yang menurut keturunan dan status sosial berasal dari bangsawan (aristokrat), pemimpin adat, ulama atau rakyat jelata mengikuti pendidikan pada jenjang dasar di HIS (Hollands Inlansche School) selama 3 sampai 5 tahun, lalu mamasuki sekolah peralihan SLO (setingkap SMP) selama 3 atau 4 tahun, seterusnya ke AMS (SMA) selama 3 tahun. Kemudian keperguruan tinggi..24 Lama waktu tempuh pendidikan bagi bumiputera lebih lama sekitar 20-21 tahun. Itu berarti 3 tahun lebih lama bila dibandingkan dengan sekolah bangsa Eropa atau yang dipersamakannya, belum termasuk diskriminasi kurikulum.

Diferensiasi pendidikan yang dilakukan pemerintah kolonial Belanda tidak dilakukan oleh pemerintah Jepang. Jepang menerapkan kebijakan penyeragaman sekolah bagi seluruh penduduk Indonesia baik dari golongan atas (Bangsawan dan sejenisnya) maupun dari golongan bawah (Rakyat jelata). Mereka mempunyai kesempatan menempuh pendidikan di lembaga pendidikan yang sama. Suatu paradigma yang cukup tajam dari politik pecah belah (devide et empera) diganti dengan politik integrasi. Semua ormas, baik nasionalis maupun religius yang pada

\footnotetext{
${ }^{23}$ Assegaf, Pendidikan.... hlm. 118-119

${ }^{24}$ Ibid. hlm. 119
} 
era kolonial Belanda berkembang secara parsial, disatukan dalam satu wadah, misalnya Masyumi.

Dimasa pendudukan Jepang banyak terjadi perubahan dalam sistem pendidikan. Karena dihapusnya sistem penggolongan, baik menurut bangsa maupun menurut status sosial. Beberapa perubahan mendasar tersebut dapat adalah sebagai berikut:

1. Jenjang Sekolah Dasar atau Sekolah Rakyat (Kekumin Gakko), terbuka bagi semua golongan penduduk tanpa diskriminasi status sosial. Lama pendidikannya diseragamkan menjadi enam tahun. Sekolah ini ada disemua desa dan kota atau tempat yang dulunya terdapat Sekolah Dasar, Sekolah Kelas Satu, Kelas Dua atau HIS dan ELS.

2. Jenjang Sekolah Lanjutan Pertama (Shoto Chu Gakko) atau sekarang setingkat SMP, terbuka bagi semua golongan penduduk yang memiliki Ijazah SR. Sedangkan Sekolah Kejuruan yang ada adalah Sekolah Pertukangan (Kogyo Gakko), Sekolah Pertanian (Nogyo Gakko) dan Sekolah Pelayaran. Lama pendidikannya 3 tahun.

3. Jenjang sekolah lanjutan umum tingkat atas (Kota Chu Gakko). Lama pendidikannya 3 tahun.

4. Jenjang Sekolah Tinggi. Pada tingkat ini hampir seluruh sekolah tinggi ditutup. Kecuali yang masih ada ialah Sekolah Kedokteran Tinggi (Ika Dai Gakko) di Jakarta, Sekolah Obat (Yaku Gakko) di Jakarta, Sekolah Kedokteran Gigi (Sika Gakko) di Surabaya, Sekolah Tekhnik Tinggi (Kagyo Dai Dakko) yang dibuka tahun 1944 di Bandung, Sekolah Tinggi Kedokteran Hewan di Bogor, Akademi pemerintahan (Kenkoku Gakko In) yang dibuka pada awal tahun 1945 di Jakarta sebagai ganti MOSVIA pada masa Belanda. ${ }^{25}$

${ }^{25}$ Ibid. hlm. 122-123 
Walaupun disatu sisi kebijakan pendidikan oleh pemerintah Jepang ini ada aspek positifnya karena penyeragaman sekolah, namun disisi lain ternyata ada aspek kekurangannya, terutama dilihat dari jumlah sekolah yang jauh lebih sedikit dari era penjajahan Belanda. Sekolah Dasar menurun jumlahnya dari 21.500 menjadi 13.500, Sekolah Lanjutan dari 850 menjadi 20, begitu pula jumlah murid sekolaj dasar menurun sebanyak $30 \%$ dan murid sekolah menengah merosot 90\%. Jumlah guru sekolah dasar menurun 35\% dan guru sekolah menengah merosot 95\%. ${ }^{26}$ Penyebabnya antara lain adalah beratnya tugas sebagai guru.

Materi pendidikan di era pendudukan Jepang juga mengalami pereubahan. Materi pendidikan pada masa ini adalah untuk mendukung kepentingan perang Jepang. Murid-murid sering kali ditugaskan untuk melakukan kerja bakti, membersihkan bengkel, asrama, mengumpulkan bahan-bahan untuk membuat pertahanan. Selain itu, indoktrinasi mental dan ideologi mengenai hakko Ichiu dalam rangka mencapai kemakmuran di Asia Raya bersama Jepang, memperbanyak latihan militer, pengenalan budaya Jepang, olahraga serta lagu-lagu Jepang. ${ }^{27}$

Dengan mencermati materi pendidikan diatas, jelas bahwa Jepang pada awalnya mengalami kesulitan dalam komunikasi, karena pelarangan bahasa Belanda dan bahasa-bahasa lain selain bahasa Jepang dan Indonesia yang selama ini digunakan. Namun kesulitan tersebut segera diatasi Jepang dengan upaya Nipponisasi bahasa dan kederisasi tenaga Guru. ${ }^{28}$

Hal tersebut yang nampaknya menjadi sebab menurunnya jumlah tenaga guru. Guru-guru banyak yang tidak mampu menyampaikan materi yang berubah sangat berat. Perubahan bahasa yang digunakan

\footnotetext{
${ }^{26}$ Setiyadi, Pendidikan... hlm. 139

${ }^{27}$ Assegaf, Pendidikan.... hlm. 125

${ }^{28}$ Ibid. hlm. 125-126
} 
juga menjadi kendala yang tidak mudah. Jika pada masa penjajahan kolonial Belanda, diijinkan digunakan bahasa daerah dalam proses belajar mengajar. Berbeda dalam pendidikan era penjajahan Jepang yang menghapus semua penggunakan bahasa selain bahasa Jepang dan bahasa Indonesia dalam semua aspek kehidupan.

Selain jenjang pendidikan yang telah penulis sampaikan diatas, ada juga pendidikan madrasah era penjajahan Jepang. Madrasah tersebut adalah Madrasah Awaliyah. Madrasah Awaliyah diadakan sore hari. Setiap hari Madrasah Awaliyah diikuti oleh beratus-ratus anak laki-laki dan perempuan. Usia murid Madrasah Awaliyah sekitar 7 tahun. Lama proses pembelajarannya kurang lebih satu setengah jam. Materi pelajarannya ialah belajar membaca al-Quran, Ibadah, akhlak dan keimanan sebagai latihan pelajaran agama yang dilakukan di Sekolah Rakyat (SR) pagi harinya. Madrasah Awaliyah ini dikelola oleh Majlis Islam Tinggi. ${ }^{29}$

Menurut Djohan Makmur terjadinya penurunan jumlah sekolah, murid, dan guru disebabkan pada awalnya Jepang memiliki beberapa kesulitan yang perlu diatasi, lebih-lebih guru. ${ }^{30}$ Kesulitan mengenai guru karena pemerintah kolonial Belanda tidak mempersiapkan secara khusus guru-guru bumiputera untuk sekolah-sekolah menengah, apalagi sekolah menengah atas. Kesulitan lainnya ialah mengenai buku-buku pelajaran. Semua buku pelajaran ditulis dalam bahasa Belanda, sementara pemerintah pendudukan Jepang melarang pemakaiannya. Untuk itu semua buku yang berbahasa Belanda diganti dengan buku-buku terjemahan yang dikeluarkan oleh Bunkyo Kyoku (Kantor Pengajaran). Bilamana buku-buku berbahasa Jepang atau terjemahannya tidak

${ }^{29}$ Mahmud Yunus, Sejarah Pendidikan Islam di Indonesia, (Jakarta: Mutiara Sumber Widya, 1995), hlm. 122-123

${ }^{30}$ Djohan Makmur, Sejarah Pendidikan di Indonesia Zaman penjajahan. (Jakarta:Depdikbud, 1993), hlm. 100-101 
diterima, maka para guru berusaha menerjemahkan dan menyusunnya sendiri ke dalam bahasa Indonesia. ${ }^{31}$ Di sinilah tanggung jawab yang besar dari para guru Indonesia yang menguasai bahasa Indonesia bukan hanya sebagai bahasa pengantar tetapi juga sebagai bahasa ilmiah.

Untuk menutupi kekurangan guru, pemerintah pendudukan Jepang membuka jenis-jenis pendidikan guru. Pendidikan guru ini tidak bersifat dualistik ${ }^{32}$ sebagaimana terjadi pada masa pemerintahan kolonial Belanda. Jenis pendidikan guru tersebut ada tiga jenis sekolah, yaitu:

1. Sekolah Guru (SG) 2 tahun, yang dinamakan Sjootoo Sihan Gakko

2. Sekolah Guru Menengah (SGM) 4 tahun, yang dinamakan Guutoo Sihan Gakko

3. Sekolah Guru Tinggi (SGT) 6 tahun, yang dinamakan Kootoo Sihan Gakkoo. ${ }^{33}$

Tabel: Rasio jumlah sekolah era Penjahan Jepang dan belanda

\begin{tabular}{|c|l|c|c|}
\hline NO & Jenjang Pendidikan & Belanda & Jepang \\
\hline 1 & Sekolah Dasar (SR) & 21.500 & 13.500 \\
\hline 2 & Sekolah Lanjutan & 850 & 20 \\
\hline
\end{tabular}

Demikianlah pembahasan pendidikan Islam era penjajahan Jepang yang penulis bahas. Berdasarkan pembahasan diatas dapat kita cermati terdapat perbedaan sistem pendidikan dengan pemerintahan kolonial Belanda. Perbedaan-perbedaan tersebut berimplikasi positif dan negatif.

31 Soegarda Poerbakawatja. Pendidikan Dalam Alam Kemerdekaan Indonesia. (Jakarta:Gunung Agung, 1970), hlm. 292-294

${ }^{32}$ Seperti kita ketahui, bahwa pada zaman kolonial Belanda terdapat dua jalur pendidikan, yaitu jalur untuk pendidikan anak-anak Belanda dan jalur untuk pendidikan anak-anak bumiputera. Bahasa pengantarnya pun berbeda, yang satu menggunakan bahasa Belanda sedangkan yang kedua menggunakan bahasa Indonesia/Melayu. Sistem pendidikan yang demikian memang disesuaikan dengan keadaan masyarakat waktu itu, yaitu masyarakat kolonial dan masyarakat bumiputera.

${ }^{33}$ Makmur, Sejarah Pendidikan... hlm. 104 


\section{Bagan Pendidikan Era Penjajahan Jepang}

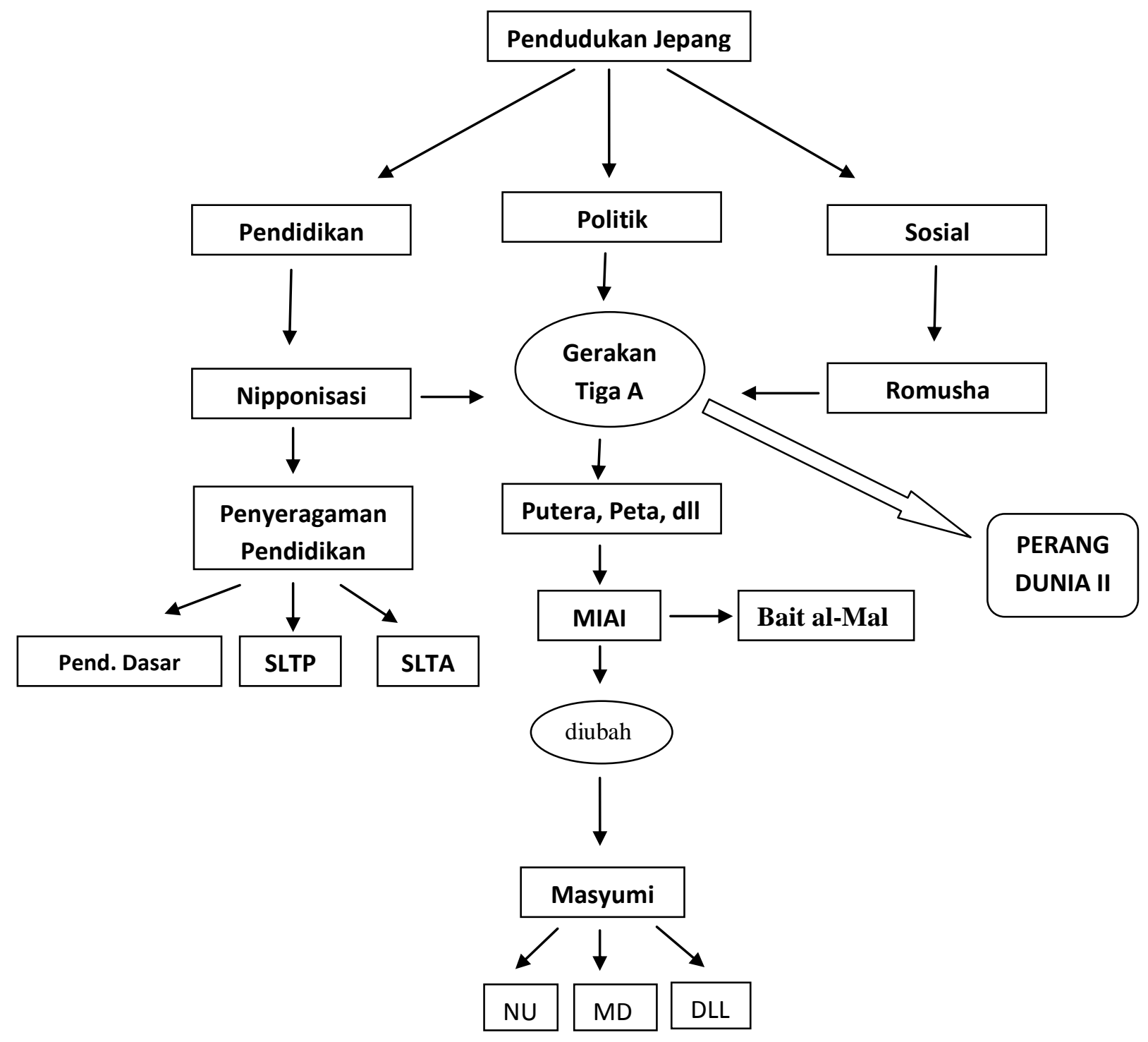

\section{KESIMPULAN}

Kebijakan pendidikan pada masa penjajahan Jepang memiliki perbedaan dengan kebijakan pendidikan yang diterapkan masa kolonial Belanda. Pada era penjajahan Belanda tidak semua orang bisa sekolah, hanya golongan atas, anak pejabat atau priyai yang bisa masuk sekolah. Sedangkan rakyat jelata tidak diijinkan sekolah. Karena pada waktu itu orientasi Belanda menjajah Indonesia untuk menguras sumber daya alam Indonesia. Berbeda dengan dengan Belanda, era penjajahan Jepang, semua 
orang bisa menempuh pendidikan baik anak pejabat ataupun rakyat biasa. Kebijakan pendidikan ini tentu beralasan. Pada waktu itu Jepang sedang menghadapi peperangan melawan sekutu. Oleh sebab itu, kebijakan pendidikan yang diterapkan jepang adalah untuk membantu mereka menghadapi sekutu.

Perbedaan kebijakan pada dua penjajah ini memberikan dampak yang positif dan negatif. Namun dampak negatifnya lebih banyak. Dampak positif dari penyeragaman sekolah yang diterapkan pemerintah Jepang adalah semua orang bisa sekolah. Bahasa Indonesia dapat dikenal oleh semua rakyat. Dampak negatifnya adalah materi yang diberikan hanya berupa doktrin-doktrin Nippon sebagai upaya untuk mendapat dukungan bangsa Indonesia menghapai sekutu.

Demikian makalah sederhana yang penulis sampaikan. Masukanmasukan dari pembaca sangat penulis harapkan untuk perbaikan makalah ini. Semoga kita dapat mengambil hikmah dari pembahasan yang kita kaji ini. 


\section{DAFTAR PUSTAKA}

Assegaf, Abdurrahman, Pendidikan Islam di Indonesia, Yogyakarta: Suka Press, 2007

J. Benda, Harry, Bulan Sabit dan Matahari Terbit, Jakarta: Pustaka Jaya, 1980

Makmur, Djohan, Sejarah Pendidikan di Indonesia Zaman penjajahan, Jakarta:Depdikbud, 1993

Poerbakawatja, Soegarda, Pendidikan Dalam Alam Kemerdekaan Indonesia, Jakarta:Gunung Agung, 1970

Rifa'I, Muhammad, Sejarah Pendidikan Nasional, Yogyakarta: Ar-ruzz Media, 2011

Salim, Agus, Indonesia Belajarlah! Membangun Pendidikan Indonesia, Yogyakarta: Tiara Wacana, 2007

Setiyadi, Pendidikan di Indonesia dari Zaman ke Zaman, Jakarta: Departemen Pendidikan dan Kebudayaan, 1979

Yunus, Mahmud, Sejarah Pendidikan Islam di Indonesia, Jakarta: Mutiara Sumber Widya, 1995

Zuhairini,dkk, Sejarah Pendidikan Islam, Jakarta: PT. Bumi aksara, 2000

Faza Adhima, "Sejarah Indonesia pada Masa Penjajahan Jepang" dalam http://www.slideshare.net. Akses tanggal 05 Nopember 2014 